12. Beck JM, Warnock ML, Curtis JL, et al. Inflammatory responses to Pneumocustis carinii in mice selectively depleted of helper T lymphocytes. Am J Respir Cell Mol Biol 1991;5:186-97.

13. Tosato G, Magrath I, Koski I, Dooley N, Blaese M. Activation of suppressor T cells during Epstein-Barr-virus-induced infectious mononucleosis. N Engl J Med 1979:301:1133-7.
14. Reinherz EL, O'Brien C. Rosenthal P, Schlossman SF. The cellular basis for viral-induced immunodeficiency: analysis by monoclonal antibodies. J Immunol 1980;125:1269-74.

15. Haron E. Bodey GP, Luna MA, Dekmezian R, Elting L. Has the incidence of Pneumocystis carinii pneumonia in cancer patients increased with the AIDS epidemic? Lancet 1988;2:904-5.

\title{
Soluble Tumor Necrosis Factor Receptors Correlate with Parasitemia and Disease Severity in Human Malaria
}

\author{
Peter Kern, Christoph Josef Hemmer, Harald Gallati, \\ Stefan Neifer, Peter Kremsner, Manfred Dietrich, \\ and Franz Porzsolt
}

\begin{abstract}
Sektion Infektionskrankheiten und Tropenmedizin, Abteilung Innere Medizin III und Tumorzentrum der Universität Ulm, Bernard-NochtInstitut für Tropenmedizin, Hamburg, and Landesinstitut für Tropenmedizin, Berlin, Germany; F. Hoffman-LaRoche, Ltd.. Pharmaceutical Research-New Technologies, Basel, Switzerland
\end{abstract}

\begin{abstract}
Elevated serum or plasma concentration of immunoreactive tumor necrosis factor (TNF) is consistently detected in patients with malaria. TNF levels correlate with high parasitemia and clinical severity but not always with outcome. Since the effects of TNF may be neutralized by soluble TNF receptors, sera of 30 nonimmune patients with malaria were analyzed before and during antimalarial therapy. High concentrations of receptors R1 (55 kDa) and R2 (75 kDa) were detected immunologically in all sera of untreated patients. Levels of immunoreactive TNF correlated closely with levels of soluble TNF R1 and R2 $(r=.75$ and .59 , respectively). In contrast, sera lacked cytotoxic activity against target cells in the TNF bioassays. Soluble TNF receptor levels remained elevated for days after treatment. These results suggest that excessive release of TNF induced by the asexual stage of malaria parasites is controlled by a subsequent shedding of soluble TNF receptors that may bind and deactivate biologically functional TNF.
\end{abstract}

Regulatory mechanisms are needed to control the potentially hazardous biologic effects of cytokines, such as tumor necrosis factor (TNF). As recently reviewed [1], malaria is associated with increased production and release of TNF, and malaria symptoms are similar to those observed after administration of TNF. To exert either beneficial or harmful effects in the host, TNF must interact with receptors on target cells. Two immunologically distinct cellular TNF receptors ( $R 1$ and $R 2$ ) have recently been identified and characterized by molecular cloning techniques [2]. $\mathrm{Rl}$ is $55 \mathrm{kDa}$ and $\mathrm{R} 2$ is $75 \mathrm{kDa}$, and each mediates distinct cellular responses [3]. As well as being differentially expressed on TNF target cells [4], these two receptors are also found in biologic

Received 16 March 1992; revised 20 May 1992.

Informed consent was obtained from patients or close relatives. The Hamburg State Medical Association approved the study protocol.

Grant support: Deutsche Forschungsgemeinschaft (Di 355).

Reprints or correspondence: Dr. Peter Kern, Section of Infectious Diseases, University of Ulm, Robert-Koch-Str. 8, D-7900, Ulm, Germany.

The Journal of Infectious Diseases 1992;166:930-4 (C) 1992 by The University of Chicago. All rights reserved. $0022-1899 / 92 / 6604-0040 \$ 01.00$ fluids [5], where they may buffer excessive TNF or act as a transport protein from which biologically active TNF is slowly released [2].

High serum concentrations of immunoreactive TNF are associated with disease severity in falciparum malaria [1]. TNF is probably released in response to schizont rupture [6]. Several studies have found close correlations between parasitemia and immunoreactive TNF [7-9]. However, TNF serum levels are low in some cases of comatose or fatal malaria but extremely high in some survivors who experience only minor complications. Supportive treatment of severe malaria with neutralizing anti-TNF antibodies has been proposed, but this strategy may not take into account regulatory mechanisms involving soluble TNF receptors. Therefore, we have analyzed the levels of $R 1$ and $R 2$ in 30 nonimmune patients with malaria.

\section{Materials and Methods}

Patients. Thirty patients with malaria were treated in the clinical department of the Tropical Institut in Hamburg between January and April 1990. Except for 3 African immi- 
grants, who had lived in Germany $\geqslant 2$ years, all patients were Europeans (ages, 16-65 years; 22 male, 8 female). All but 1 had contracted malaria while traveling in Africa, most for the first time. Malaria was diagnosed in thick and thin blood films. Twenty-seven patients suffered from Plasmodium falciparum and 3 from Plasmodium vivax infections. All received adequate antimalarial treatment $[8,10]$. Nine patients with $P$. falciparum malaria had one or more complications, which caused them to be classified as having severe malaria [8]. Of these 9 patients, 6 had impaired cerebral function (disorientation, drowsiness, and unconsciousness), and 3 had abnormal global clotting tests (prothrombin time activity $<50 \%$ and partial thromboplastin time $>45 \mathrm{~s}$ ). Other complications included renal dysfunction ( 3 patients: serum creatinine $>176 \mu \mathrm{mol} / \mathrm{L}$ or $2 \mathrm{mg} / \mathrm{dL}$ ) and respiratory insufficiency ( 1 patient: $\mathrm{PO}_{2}<70 \mathrm{~mm} \mathrm{Hg}$ ). One patient died $24 \mathrm{~h}$ after admission and start of treatment.

Blood samples. Samples were obtained in accordance with the hospital's routine blood sampling protocol [10]. Samples were obtained on day 0 (before treatment) and on days 1, 2, 4, and 7 of therapy for parasite, differential blood cell, and platelet counts and for coagulation parameters, neopterin, and blood chemistry (including creatinine, liver transaminases, and serum electrolytes). Parasites were counted in 2000 erythrocytes for calculation of parasitemia. Serum samples were prepared immediately by centrifugation $(2000 \mathrm{~g})$ for $10 \mathrm{~min}$ at room temperature, and suitable aliquots were stored at $-80^{\circ} \mathrm{C}$ until analysis. Samples from 5 healthy volunteers were included as controls.

Analysis of TNF and soluble TNF receptors in sera. TNF serum concentrations were determined in duplicate by a sandwich immunoradiometric assay (IRMA) (EIA; Medgenix, Fleurus, Belgium). Bioactivity of TNF was assayed colorimetrically as cytotoxicity to L929 cells and to mouse fibrosarcoma cells WEHI 164 [11]. Human recombinant TNF (specific activity, $6 \times 10^{7}$ units $/ \mathrm{mg}$ as determined by the supplier in a bioassay with murine tumor cells) and a polyclonal rabbit antibody to human TNF (neutralizing capacity, $2 \times 10^{5}$ units $/ \mathrm{mL}$ ) were provided by G. R. Adolf (Ernst-Boehringer-Institut, Vienna). Serial sample dilutions were tested in duplicate. A serum dilution causing $50 \%$ cell lysis was defined as containing $1 \mathrm{unit} / \mathrm{mL}$ TNF. Calculation was done by probit analysis.
The soluble TNF receptor assays were designed to detect only functionally active receptor fragments by using enzyme-labeled recombinant human $T N F$ as the revealing agent. Simultaneous presence of $<10 \mathrm{ng} / \mathrm{mL}$ TNF in plasma did not influence the results, indicating that free as well as reversibly occupied soluble TNF receptor molecules were detected. Briefly, the purified monoclonal mouse antibodies, clone utr-4 against TNF R1 (55 $\mathrm{kDa}$ ) and clone htr-20 against TNF R2 (75 kDa), were coated on microtiter plates (Immuno Plate, Maxisorp F 96; Nunc, Roskilde, Denmark). For determination of soluble TNF receptors, the samples and standards (0-5 ng/mL Rl and R2) were incubated in the coated microtiter plates (immunologic binding). At the same time, recombinant TNF-horseradish peroxidase conjugate (biologic binding) was added to the test solution. After washing, peroxidase bound to the microtiter plate was measured enzymatically. The detection limit of the two ELIBAs (Hoffman-La Roche) is $\sim 100 \mathrm{pg} / \mathrm{mL}$ for both soluble TNF Rl and R2.

Statistical analysis. Levels of significance were determined by nonparametric tests (Wilcoxon-Mann-Whitney). Spearman correlation coefficients between different parameters were calculated.

\section{Results}

TNF concentration and activity. Elevated immunoreactive TNF serum levels ( $>20 \mathrm{pg} / \mathrm{mL})$ were found in all sera of malarial patients before treatment (table 1). TNF levels correlated with parasitemia $(r=.51)$, serum neopterin $(r=$ .59 ), a second line marker of macrophage activation, and with low platelet counts $(r=-.59)$. Patients with cerebral symptoms or coagulation abnormalities, which by definition identified them as having complicated malaria, had higher serum TNF concentrations than those with uncomplicated falciparum malaria or vivax malaria $(P=.028)$. In addition, the serum levels of neopterin, enabled the two groups to be distinguished $(P=.0009)$. Sera were examined for TNF bioactivity by $\mathrm{L} 929$ and WEHI 164 bioassays. Using human

Table 1. Cell counts or concentrations (median and range) in untreated malaria patients.

\begin{tabular}{|c|c|c|c|c|c|}
\hline Parameters & $\begin{array}{l}\text { Normal } \\
\text { range }\end{array}$ & $\begin{array}{c}\text { Uncomplicated } \\
\text { falciparum }(n=18) \\
\text { or vivax malaria }(n=3)\end{array}$ & $P$ & $\begin{array}{c}\text { Complicated } \\
\text { falciparum malaria } \\
(n=9)\end{array}$ & $\begin{array}{c}\text { All patients } \\
(n=30)\end{array}$ \\
\hline Parasitized erythrocytes $/ \mu \mathrm{L}$ & None & $18(4.5-133.0)$ & .0272 & $182(3-758)$ & $30(3-758)$ \\
\hline Platelet count/ $\mu \mathrm{L}$ & $150-450$ & $89(38-297)$ & .0051 & $29(9-137)$ & $78(9-297)$ \\
\hline Neopterin (nmol/L) & $<10^{*}$ & $69(28-140)$ & .0009 & $161(75-750)$ & $81(28-750)$ \\
\hline TNF IRMA (pg/mL) & $<15^{*}$ & $83(24-186)$ & .0283 & $189(59-518)$ & $87(24-518)$ \\
\hline TNF bioassays (pg/mL) & $<40^{*}$ & $<40$ & NA & $<40$ & $<40$ \\
\hline \multicolumn{6}{|c|}{ Soluble TNF receptors $(\mathrm{ng} / \mathrm{mL})$} \\
\hline $\mathrm{R} \perp(55 \mathrm{kDa})$ & $1.2-2.0^{*}$ & $4.6(1.3-13.2)$ & .0007 & $18.5(6.1-43.8)$ & $5.8(1.3-43.8)$ \\
\hline $\mathrm{R} 2(75 \mathrm{kDa})$ & $0.2-1.4^{*}$ & $9.5(2.4-19.9)$ & .0007 & $47.2(12.0-118.3)$ & $11.5(2.4-118.3)$ \\
\hline TNF:TNF receptor ratio ${ }^{\dagger}$ & NA & $3.0(1.4-6.1)$ & NA & $5.5(2.0-11.1)$ & $5.1(1.4-11.1)$ \\
\hline
\end{tabular}

NOTE. IRMA, immunoradiometric assay; NA, not applicable.

* Healthy controls $(n=5)$.

+ TNF IRMA divided by sum of both soluble TNF receptors (p55 and p75). 
recombinant TNF as a standard, the lower detection limit of the WEHI 164 assay was $40 \mathrm{pg} / \mathrm{mL}$ TNF. Bioactive TNF could not be detected in sera in any of the cytotoxicity assays (table 1).

$T N F$ receptor proteins. The serum concentrations of soluble TNF receptors ( $R 1$ and $R 2$ ) were increased in patients with malaria compared to controls (table 1 ). The serum levels of both R1 and R2 correlated with those of TNF determined by IRMA ( $r=.75$ and .59 , respectively). In addition, soluble TNF receptor levels were associated with disease severity ( $P=.0007$ for both receptors). The highest $\mathrm{R} 1$ and $\mathrm{R} 2$ levels were observed in 6 patients with cerebral malaria. In 1 patient who died $24 \mathrm{~h}$ after admission and start of treatment,
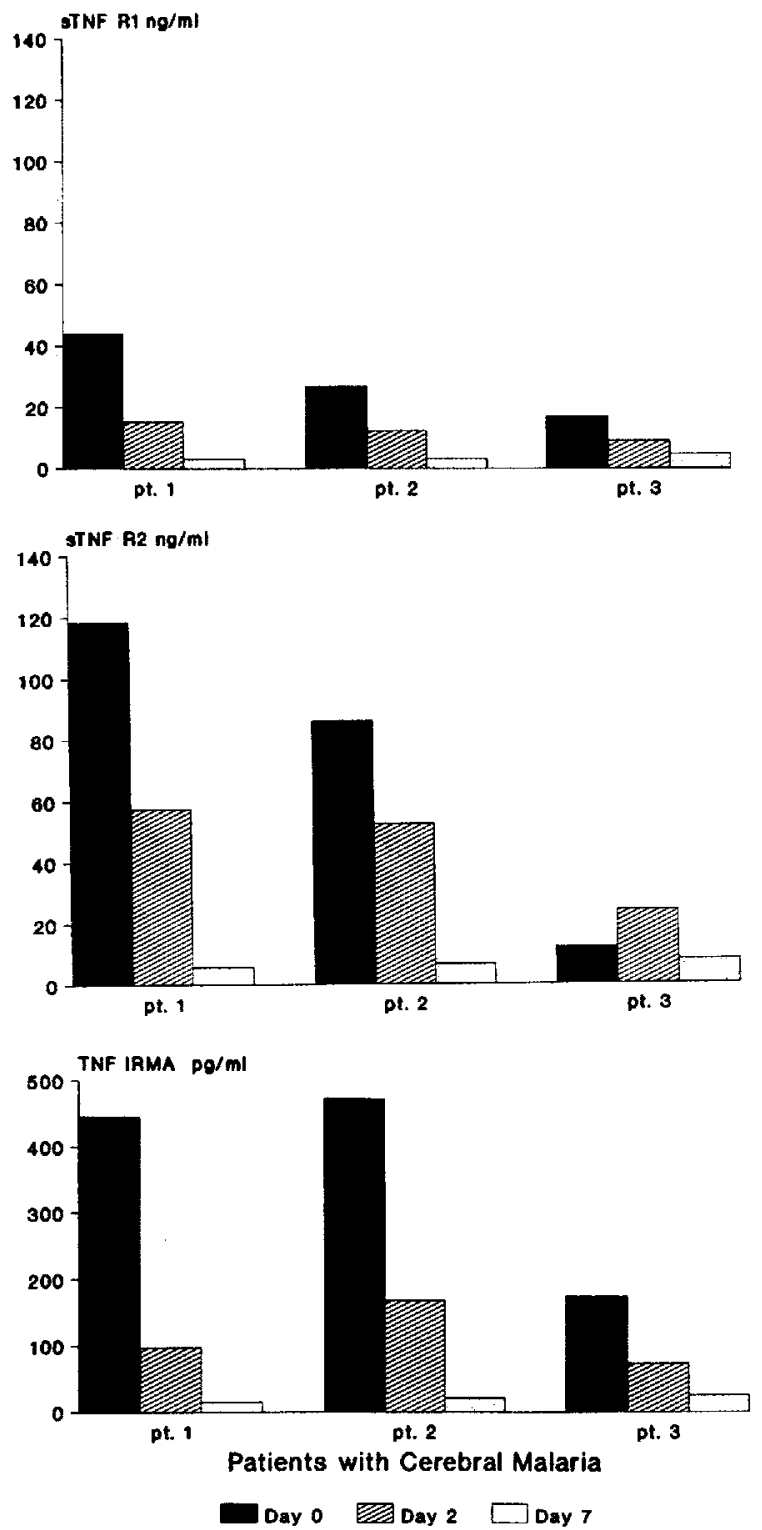

the pretreatment serum IRMA TNF level was $232 \mathrm{pg} / \mathrm{mL}$, and no bioactive TNF was detectable by bioassay. $R 1$ and $\mathrm{R} 2$ concentrations were increased $(24.0$ and $65.1 \mathrm{ng} / \mathrm{mL}$, respectively) in this patient. The TNF to soluble TNF receptor ratio might provide an estimate of the relative excess of TNF. The median ratio of patients with complicated malaria was about half that of patients with uncomplicated malaria ( 3.0 vs. 5.5 ; table 1 ). This may indicate that in response to severe infection the available soluble TNF receptors are reduced.

TNF IRMA and receptor levels during chemotherapy. Specific antimalarial treatment led to a rapid clearance of parasitemia, defervescence, and normalization of laboratory


Figure 1. Serum concentrations of TNF and soluble TNF (sTNF) receptors in patients with falciparum malaria before, during, and after chemotherapy. Follow-up data on 3 patients with cerebral malaria (pt. 1-3) and 3 with uncomplicated malaria (pt. 4-6) are shown. IRMA, immunoradiometric assay. 
parameters within days in 29 patients. Samples from 6 patients, 3 of whom presented with cerebral symptoms, were studied during follow-up. In complicated falciparum malaria, $R 1$ and $R 2$ decreased rapidly during the first 2 days as did the TNF levels (figure 1). In cases of uncomplicated malaria, the pretreatment soluble TNF receptor levels were increased compared to those of controls; however, day 2 levels remained in the same range. Increased concentrations of the receptors were detected in sera of all 6 patients 7 days after the start of treatment, regardless of the initial quantity (median concentrations for $\mathrm{R} 1$ and $\mathrm{R} 2: 2.9$ and $6.1 \mathrm{ng} / \mathrm{mL}$, respectively). This suggests that receptor turnover remains enhanced and that TNF-responsive systems may still be activated.

\section{Discussion}

Elevated serum concentrations of TNF R 1 and R2 were observed in all 30 patients under study; exceptionally high levels were found in patients with complicated malaria. Also, concentrations of $\mathrm{R} 1$ and $\mathrm{R} 2$ correlated closely with those of immunoreactive TNF ( $r=.75$ and .59$)$. This might reflect the fact that most immunologic assays for TNF detect this cytokine both in its native form and in complex with receptor proteins [12]. Serum levels of TNF R2 in our malarial patients exceeded those of $\mathrm{R} 1$ in all but 1 patient.

We reanalyzed TNF serum levels by bioassay using two TNF-sensitive cell lines. In both assays the cytotoxic activity serves as the main parameter of TNF bioactivity. None of the samples, including those with the highest TNF serum levels and those from the patient who died of malaria, were found to affect the growth of the TNF-sensitive cell lines. An explanation may be that any TNF in the samples may have been neutralized in vitro by an excess of soluble TNF receptors. Furthermore, biologically functional TNF may be deactivated in vivo as well, although there are several arguments against this explanation. Sera from malarial patients (immunoreactive TNF-detectable) up-regulate synthesis of tissue factor by endothelial cells from human umbilical veins in a dose-dependent manner that corresponds to the concentration of immunoreactive TNF [10]. In addition, elevated serum interleukin-6 (IL-6) concentrations have been found, and the bioactivity could be neutralized in patient's sera using oligoclonal anti-IL-6 antibodies [8]. We have also found the TNF-inducible intercellular adhesion molecule 1 to be up-regulated on circulating monocytes of these patients (unpublished data). Thus, the failure to detect bioactive TNF in sera containing high concentrations of soluble TNF receptors does not allow us to conclude that the increased concentrations of IRMA TNF are irrelevant in vivo.

As recently demonstrated [3], the binding of TNF to TNF R1 or R2 seems to initiate distinct signaling pathways and therefore mediate different cellular responses. Binding to R I leads to cytotoxicity and antiviral activity at high TNF concentrations, whereas binding to $\mathrm{R} 2$ stimulates proliferation of thymocytes and $\mathrm{T}$ lymphocytes at low TNF concentrations. However, the specific function of each receptor is still under debate [2]. The observed close correlation of immunoreactive TNF and soluble TNF receptors may mean there is another second line marker of immune activation, similar to neopterin or IL-6, which was elevated in most of the samples from these patients (data not shown; R1 and R2 correlation coefficients, $r=.44$ and .41 , respectively).

Interestingly, the relative excess of soluble TNF receptors becomes smaller in patients with complicated malaria as roughly calculated from our data. Thus, the neutralizing effects of soluble TNF receptors may help to prevent the potentially harmful effects of TNF in an uncomplicated clinical situation but may fail in cases of excessive TNF production.

TNF-mediated diseases can be overcome not only by TNF-specific monoclonal antibodies [1] or inhibitors of TNF synthesis [13] but also by recombinant TNF-receptor proteins as has recently been shown in animal models [14]. Therefore, it may be possible to analyze the therapeutic effect of these molecules in a suitable animal model, such as Plasmodium vinckei malaria [15]. If administration of these receptor proteins prevents complications, studies on human malaria might compare the efficacy of different ways to neutralize or reduce excessive amounts of circulating TNF.

\section{Acknowledgments}

We thank R. Barthel, A. Bildhauer, K. Braker, I. Pracht, E. Scharr, and S. Weber for technical, organizational, and secretarial assistance and I. Clark, Canberra, Australia, T. Calandra, New York, and H.-D. Flad, Borstel, Germany, for valuable comments and critical reading of the manuscript.

\section{References}

1. Clark IA, Rockett KA, Cowden WB. TNF in malaria. In: Beutler B, ed Tumor necrosis factors: the molecules and their emerging role in medicine. New York: Raven Press, 1992:303-28.

2. Tartaglia LA, Goeddel DV. Two TNF receptors [brief review]. Immunol Today 1992;13:151-3.

3. Tartaglia LA, Weber RF. Figari IS, Reynolds C, Palladino MA Jr., Goeddel DV. The two different receptors for tumor necrosis factor mediate distinct cellular responses. Proc Natl Acad Sci USA 1991;88:9292-6.

4. Brockhaus M, Schoenfeld HJ, Schlaeger EJ, Hunzinger W, Lesslauer W, Loetscher H. Identification of two types of tumor necrosis factor receptors on human cell lines by monoclonal antibodies. Proc Natl Acad Sci USA 1990;87:3127-31.

5. Engelmann H, Novick D, Wallach D. Two tumor necrosis binding 
proteins purified from human urine. Evidence for immunological cross-reactivity with cell surface tumor necrosis factor receptors. J Biol Chem 1990;265: 1531-6.

6. Kwiatowski D, Cannon IG, Manogue KR, Cerami A, Dinarello CA. Greenwood BM. Tumor necrosis factor production in falciparum malaria and its association with shizont rupture. Clin Exp Immunol $1989 ; 77: 361-6$.

7. Grau GE, Taylor TE. Molyneux ME, et al. Tumor necrosis factor and disease severity in children with falciparum malaria. $\mathrm{N}$ Engl J Med 1989;320:1586-91.

8. Kern P, Hemmer CJ, Van Damme J, Gruss HJ, Dietrich M. Elevated tumor necrosis factor alpha and interleukin- 6 serum levels as markers for complicated Plasmodium falciparum malaria. Am J Med 1989;87:139-43.

9. Kwiatkowski D, Hill AVS, Sambou I, et al. TNF concentration in fatal cerebral, non-fatal cerebral, and uncomplicated Plasmodium falciparum malaria. Lancet 1990;336:1201-4.

10. Hemmer CJ, Kern P, Holst FGE, et al. Activation of the host response in human Plasmodium falciparum malaria: relation of parasitemia to tumor necrosis factor/cachectin, thrombin-antithrombin III, and protein C levels. Am J Med 1991;91:37-44.

11. Espevik T, Nissen-Meyer J. A highly sensitive cell line. WEHI 164 clone 13, for measuring cytotoxic factor/tumor factor from human monocytes. J Immunol Methods 1986;95:99-105.

12. Engclberts I, Stephens S, Francot GJM, van der Linden CJ, Buurman WA. Evidence for different effects of soluble TNF-receptors on various TNF measurements in human biological fluids [letter]. Lancet 1991;338:515-6.

13. Kremsner PG, Grundmann $H$, Neifer $S$, et al. Pentoxifylline prevents murine cerebral malaria. J Infect Dis 1991;164:605-8.

14. Lesslauer W, Tabuchi H. Gentz R, et al. Recombinant soluble tumor necrosis factor receptor proteins protect mice from lipopolysaccharide-induced lethality. Eur J Immunol 1991;21:2883-6.

15. Clark IA, MacMiking JD, Gray KM, Rockett KA, Cowden WB. Malaria mimicry with tumor necrosis factor. Contrasts between species of murine malaria and Plasmodium falciparum. Am J Pathol 1992;140:325-36. 